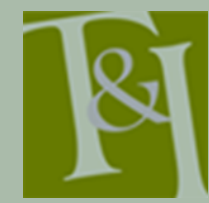

The International Journal for Translation \& Interpreting Research trans-int.org

\section{"I feel we don't really understand each other": Interpreting medication instructions for a Turkish-speaking diabetes patient}

\author{
Gertrud Hofer \\ Zurich University of Applied Sciences \\ gertrud.hofer-falk@uzh.ch \\ Marcel Eggler \\ Zurich University of Applied Sciences \\ eggm@zhaw.ch
}

\section{Marina Sleptsova \\ University Hospital Basel \\ Marina.Sleptsova@usb.ch}

Wolf Langewitz

University Hospital Basel

Wolf.Langewitz@usb.ch

DOI: 10.12807/ti.107203.2015.a05

\begin{abstract}
This paper is based on a videotaped diabetes consultation involving a German-speaking physician, a Turkish-speaking diabetes patient and a TurkishGerman interpreter who has been working in medical settings for a number of years. In the course of the consultation, the physician focuses several times on the importance of the patient carefully maintaining a balance of food intake and insulin supply in order to control his diabetes. The discourse-based analysis indicates the cognitive task load of the interpreter in this encounter when confronted with medication instructions. The data indicate that the interaction could have been more efficient if the interpreter had acquired the necessary knowledge about diabetes prior to the consultation or if she had recognised the elements structuring the discourse. In fact, the interpreter cannot establish a successful communication pertaining to the blood glucose-insulin mechanism between the doctor and the patient. The patient himself seems to have more in-depth knowledge about diabetes as a result of his personal experience than the interpreter has. In this paper, we therefore argue that interpreters need a sound understanding of the specific medical situation (top-down process) in order to interpret interactions adequately in a complex case such as diabetes. If interpreters lack sufficient medical knowledge in one of their varied assignments, they could use their textual competence and their capacity for formal, logical reasoning to infer connections between propositions (bottom-up process). Thus, interpreters' cognitive-linguistic competence could to some extent compensate for their lack of domain-specific understanding. Nevertheless, the data shows that interpreters need specialized training not only in analysis of linguistic discourse but also in domain-specific knowledge and terminology.
\end{abstract}

Keywords: interpreting, physician-patient communication, discourse analysis, diabetes

\section{Introduction}

This paper reports on a study using a small data set taken from a project entitled "Interpreting in medical settings: roles, requirements and responsibilities" which was conducted between 2010 and 2012. The team of researchers involved in the study compiled a corpus of 19 interactions amounting to 14:42 hours of video material. The consultations were recorded in three hospitals in Switzerland, the university hospitals of Basel and Zurich and the Inselspital in 
Bern. These three hospitals have contracts with Swiss agencies which recruit interpreters for them (cf. Hudelson, 2013, p. 2).

All of the 19 video tapes involved interpretation of Albanian and Turkish into and from German. Once the data was gathered, the Albanian and the Turkish parts were translated into German and fully transcribed by interpreters who had worked for several years as interpreters in medical settings. The interactions were analysed by linguists as well as by medical experts. For the transcription we used the EXMERaLDA software tool and a simplified version of the GAT conversation analysis transcription system (cf. Selting et al. 2009). This paper builds on Hofer et al., 2013a, in which further information on the project can be found.

The overall aim of the empirical pilot study was to deepen our understanding of a broad range of phenomena pertaining to the work of medical interpreters in various real-world situations. The interdisciplinary research team consisted of medical doctors, psychologists, linguists and interpreting researchers with different research interests. A combination of different research methods and approaches were deployed in the project (cf. Sleptsova et al., 2014; Hofer et al., 2013a). The quantitative analysis of the video material was based on pre-defined categories of inadequacies, such as changes of meaning during the interpretation or an observable lack of domain-specific expertise, to ascertain the relevance of such aspects to the effectiveness of the communicative exchange. We also wanted to explore the impact of certain behaviours on the dynamics of the discourse under observation.

In this paper, we discuss nine excerpts from one of the 19 interactions, which features the language pair German - Turkish. The nine excerpts examined are taken from a diabetic consultation and last ten minutes (16:06 - 26:15) of the whole encounter of 29 minutes, 39 seconds. The selected excerpts focus on the interpretation of the physician's $(\mathrm{PH})$ explanations of the instructions on how the patient (PAT), who has to monitor his blood glucose levels to control his diabetes, should use the medication. The interpreter (INT) is not university trained, but she does work regularly as a medical interpreter and is registered with a Swiss agency.

The analysis focuses on two questions:

- If an interpreter does not have the necessary domain-specific knowledge, does it hamper communication? If so, in what ways?

- Can interpreters bridge any knowledge gap they may have by drawing on other resources during the communicative exchange?

One of the common points of interest in the design of the original research project was the impact of interpreters' medical knowledge on the discourse in which they partook. We explored these excerpts within the context of specific aspects of discourse analysis (conjunctions and cohesion, cf. Tebble, 2007), the Effort Model applied to consecutive interpreting (Gile 2009), and models of text comprehension (Van Dijk \& Kintsch, 1983; Schnotz, 2006).

\section{Results}

In this section, the excerpts are numbered and presented in the order in which they occur during the consultation. The exchanges are transcribed according to the conventions described in section 1 (Introduction). The transcription conventions used for the excerpts are presented in Appendix A. 


\section{Excerpt 1}

Excerpt 1 starts with the physician telling the patient about the two most important objectives of the instructions:

Table 1. Transcript of Excerpt 1

\begin{tabular}{|c|c|c|}
\hline [195] & $359[16: 03.1] 360[16: 03.6]$ & $361[16: 06.5]$ \\
\hline $\begin{array}{l}\mathrm{PH}[\mathrm{v}] \\
\mathrm{PH}[\mathrm{TR}]\end{array}$ & & $\begin{array}{l}\text { im moMENT ist } \\
\text { at the moment }\end{array}$ \\
\hline [196] &. & $362[16: 11.8]$ \\
\hline \begin{tabular}{|l}
$\mathrm{PH}[\mathrm{V}]$ \\
$\mathrm{PH}[\mathrm{TR}]$ \\
$\mathrm{I}[\mathrm{V}]$ \\
$\mathrm{I}[\mathrm{TR}]$ \\
\end{tabular} & $\begin{array}{l}\text { das ZIEL bei Ihnen dass Sie KEIne unte } \\
\text { the aim for you is to avoid any hypos }\end{array}$ & $\begin{array}{l}\text { rZUCKerungen HABen. } \\
\qquad \begin{array}{l}\text { ee şimdi } \\
\text { er at the moment }\end{array}\end{array}$ \\
\hline [197] & .. & $363[16: 16.7](1)$ \\
\hline $\begin{array}{l}\mathrm{PH}[\mathrm{v}] \\
\mathrm{PH}[\mathrm{TR}] \\
\mathrm{I}[\mathrm{v}] \\
\mathrm{I}[\mathrm{TR}]\end{array}$ & $\begin{array}{l}\text { amacımız diyo önemli olan şekerinizin düşmemesidir diyo. } \\
\text { it is the aim which is important is that your sugar does not drop says she }\end{array}$ & $\begin{array}{l}\mathrm{d} \text { a } \mathrm{s} \text { i } \mathrm{s} \mathrm{t} d \mathrm{~d} \text { a } \mathrm{ER} \mathrm{S} \mathrm{t} \mathrm{e} \mathrm{d} \mathrm{a} \mathrm{s} \\
\text { this is the first }\end{array}$ \\
\hline [198] & $364[16:$ & $18.1]$ \\
\hline \begin{tabular}{|l}
$\mathrm{PH}[\mathrm{v}]$ \\
$\mathrm{PH}[\mathrm{TR}]]$ \\
$\mathrm{I}[\mathrm{v}]$ \\
$\mathrm{I}[\mathrm{TR}]$ \\
\end{tabular} & $\begin{aligned} \text { i s t d a s } \mathrm{W} I \mathrm{C} \mathrm{H} \text { t i g s t e } & \\
\text { this is the most important } & \text { bu birinc } \\
& \text { this is th }\end{aligned}$ & $\begin{array}{l}\text { ci amaç önemli olan çok önemli olan. } \\
\text { he first aim that is important that is very important }\end{array}$ \\
\hline [199] & $365[16: 21.1](2)$ & $366[16: 25.1]$ \\
\hline \begin{tabular}{|l}
$\mathrm{PH}[\mathrm{v}]$ \\
$\mathrm{PH}[\mathrm{TR}]$ \\
$\mathrm{l}[\mathrm{V}]$ \\
$\mathrm{I}[\mathrm{TR}]$ \\
\end{tabular} & $\begin{array}{l}\text { und das ZWElte ist dass der ZUCKer NICHT zu HOCH ist. hm } \\
\text { and the second is that the sugar is not too high. hm }\end{array}$ & $\begin{array}{l}\text { ikinci } \\
\text { our second }\end{array}$ \\
\hline [200] &. & $367[16: 29.7]$ \\
\hline $\begin{array}{l}\text { I [v] } \\
\text { I [TR]x }\end{array}$ & $\begin{array}{l}\text { amacımızda çok önemli olanda fazla yükselmemesidir. } \\
\text { aim that is very important is that it does not rise too high }\end{array}$ & \\
\hline
\end{tabular}

The physician describes her two objectives to the patient (no episodes of hypoor hyperglycaemia), and the interpreter reformulates the content of excerpt 1 adequately to the patient in Turkish. She even adds the word "aim" to improve the cohesion for the physician's elliptic utterance "this is the first" (1) and "the second is" (2). The patient in the video is seen to nod several times during the discourse to confirm that he understands.

\section{Excerpt 2}

In excerpt 2, the discourse centres on the long-term adjustment of the patient's medication. The main message, however, concerns the aspect the physician mentioned in excerpt 1: preventing extreme swings in blood sugar levels.

The physician's utterance is very clear: “. . at the beginning it is important no low blood glucose and no very high blood sugar level" (3), while the interpreter's wording "ortasını bulmamız lazım" (4) in Turkish (which translates into English as "to find the middle" [5]) is less domain-specific. The effect of the drug "Novorapid" is explained by the physician. This is where the processing task for the interpreter becomes more difficult. She calls the drug "Novorativ". The name is obviously unknown to her. She concentrates to keep the name in mind and thus delays the interpreting process by saying "Novorativ things ..." (7) in order to gain some "time for thought" (Gile, 2009, p. 201). During the interpreter's presumably cognitively motivated pause the patient intervenes: "lowers early" (8). This might not be a professional way of explaining the "fast acting" (6) of Novorapid that the physician had mentioned, but he does seem to understand perfectly what the physician meant. In fact, his version is nearer to the physician's than the interpreter's, who actually contradicts the patient ("No, disperses early in the body" [9]) and then adds of her own accord: "You could see the effect" (10), an addition which does not make the effect of Novorapid any clearer to the patient. The physician's original input is easier to understand than the interpreter's substitution - a situation that puts a patient dependent on an interpreter, clearly at a disadvantage (cf. Menz, 2013, p. 348). 
Table 2. Transcript of Excerpt 2

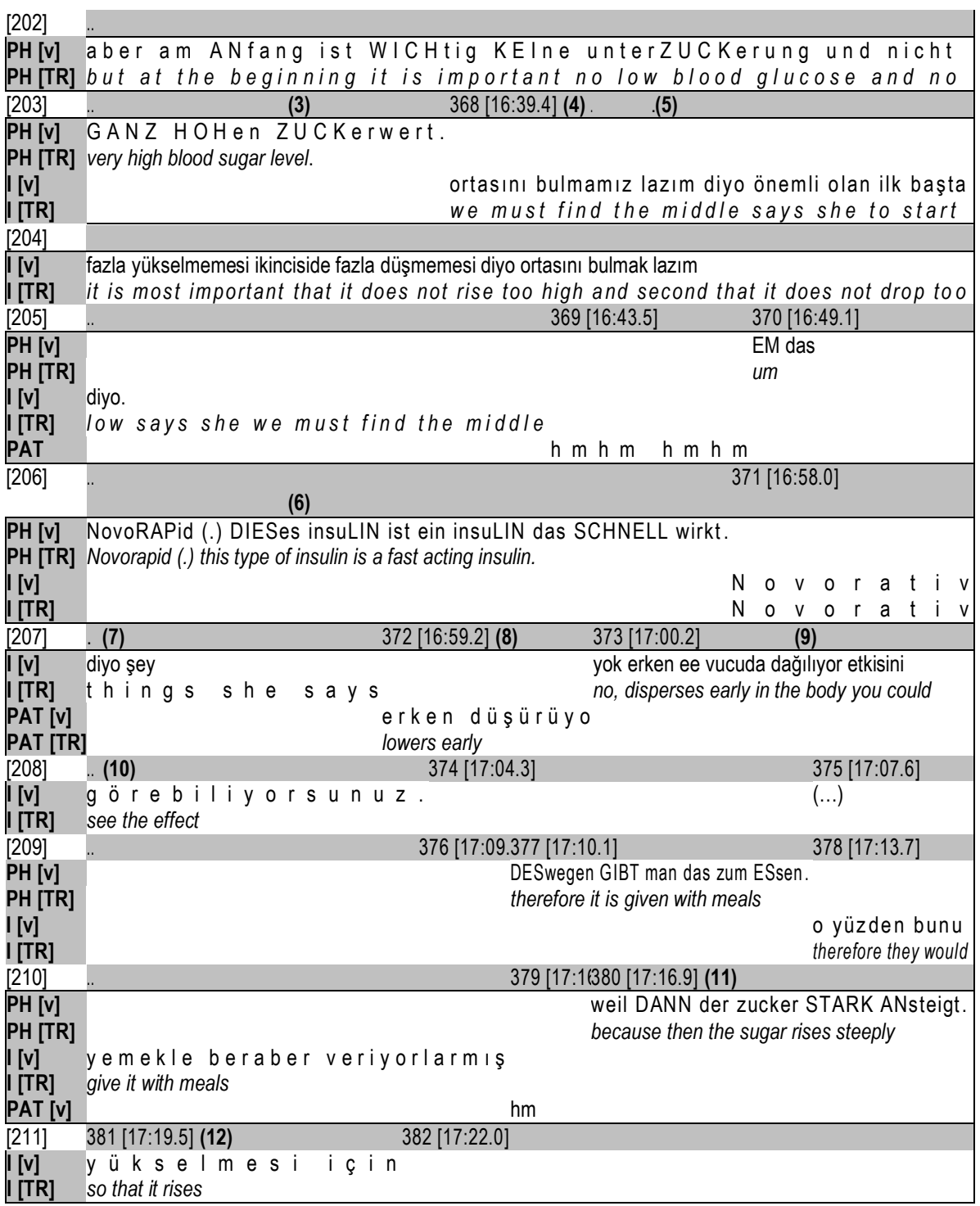

At the end of excerpt 2, the physician explains for the first time why the insulin intake with the meals has to be higher than the insulin intake between the meals "because then the sugar rises steeply" (11). The interpreter changes the logical connection "because then" to "so that" (12) and omits the temporal deictic marker. The interpreter appears to lack the necessary medical knowledge and fails to contextualize the instruction properly. By using the conjunction "because" the interpreter erroneously infers that the supply of insulin is linked to a significant rise in the blood sugar level while eating. She would have conveyed the context accurately if she had understood the role of insulin, or she may also have done so if she could have distinguished between the conjunctions of causality and purpose on a purely syntactic basis. Linguistically speaking, general causality ("because") is transformed into an intended consequence. This is also the crucial logical error made by the interpreter. Apart from that, a significant lexical item ("steeply" [11]) is omitted as well as the replacement of "sugar" in the same utterance. This leads to a loss of communicative clarity although the patient can obviously fall back on his own medical knowledge acquired in the course of his experience with diabetes. He nods even before the interpreter is ready with her version, suggesting his comprehension. His inputs "hm" are not heard by the physician. Together with the nodding, they might well indicate that he understands the physician's instructions. He may even 
think to himself that the interpreter has it wrong. The interpreter does not seem to be aware that changing the conjunctions might have an impact on the meaning, influence the dynamics of the discourse, blurring the physician's objectives and thus jeopardizing the patient's understanding of what is being described. The patient possibly has a good understanding of the role of insulin, but he does not openly disagree with the interpreter.

\section{Excerpt 3}

Hardly a minute later, the interpreter once more shows her lack of contextual knowledge when the physician explains why the insulin dose must be considerably lower between meals:

Table 3. Transcript of Excerpt 3

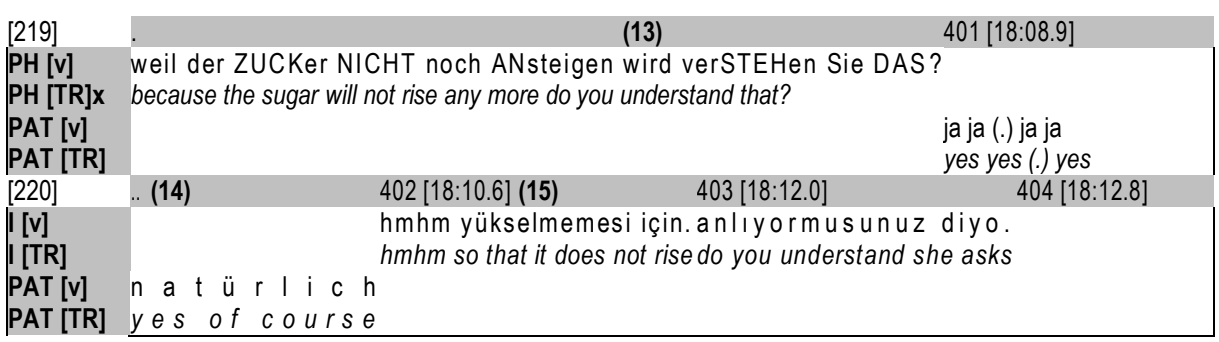

Again it becomes evident that the interpreter neither has the necessary medical background nor the knowledge of the syntactic categories to transfer the physician's instruction. Interestingly, the patient indicates that he understands, "yes, yes, yes, yes, of course" (14). He answers in German before he has heard the interpretation. We cannot be absolutely sure whether he really understands the connection. "Many patients might not understand the language of a physician well enough for a medical interaction or fear they will be unable to express their answers and questions in the language of the physician, even if they can get along linguistically in everyday situations." (Meyer, 2009). It is possible, however, that the patient might have been able to read the record of the blood sugar levels on the physician's desk or may even have remembered them (the interpreter is seated too far away and most probably cannot see the data). His comprehension may also be based on the competence he has gained through his experience of the disease, as we shall see in excerpt 4 . Whatever the case, the interpreter does not understand the connection between either the high dose of insulin and the increase in blood sugar level with meals or the need for a low dose between meals. As in excerpt 2, the interpreter replaces "because the sugar does not rise any more" (13) by "so that it does not rise" (15). The interpreted version also loses transparency through the interpreter's omission of the noun "sugar" (13) and the adverbial "any more" (13).

\section{Excerpt 4}

A minute later, in excerpt 4, the interpreter asks the physician to explain the concept to her. Obviously she is aware of her comprehension problem.

In excerpt 4, it is evident again that the interpreter fails to understand the connection. She interrupts the physician and asks for clarification ("excuse me does that mean not eat before the meal?" [16]). The physician tries to repeat her explanation that the small dose has to be taken between meals if the blood glucose is too high (17). The interpreter was not yet ready to listen to the physician as she was still concentrating on trying to understand the connection: "because before I did not understand the question" (18). The physician answers, speaking this time to the interpreter rather than the patient. She looks at the interpreter, stresses the temporal marker "then" (19) and the causality ("because") (20). 
Table 4. Transcript of Excerpt 4

\begin{tabular}{|c|c|}
\hline [223] & $412[18: 28.0]$ \\
\hline $\begin{array}{l}\mathrm{PH}[\mathrm{v}] \\
\mathrm{PH}[\mathrm{v}]\end{array}$ & $\begin{array}{l}\text { und wenn Sie SONST } \\
\text { and if you at some }\end{array}$ \\
\hline \multicolumn{2}{|l|}{ [224] } \\
\hline $\mathrm{PH}[\mathrm{v}]$ & IRGENDwann am TAG NICHT VOR dem ESsen den HOhen ZUCKer messen \\
\hline $\begin{array}{l}\text { PH [TR] } \\
{[225]}\end{array}$ & $\begin{array}{l}\text { other time of the day do not measure the high sugar level before the meal } \\
413[18: 35.0]\end{array}$ \\
\hline $\begin{array}{l}\text { [ } \\
\text { [ [TR] }\end{array}$ & $\begin{array}{l}\text { TSCHULdigung he is st } \\
\text { excuse me does that mean }\end{array}$ \\
\hline [226] & $415[18: 42.0]$ \\
\hline $\begin{array}{l}\mathrm{PH}[\mathrm{v}] \\
\mathrm{PH}[\mathrm{TR}]\end{array}$ & $\begin{array}{l}\text { ja also NICHT jetzt DIEses am MORgen er } \\
\text { well not this one in the morning he said }\end{array}$ \\
\hline $\mathrm{I}[\mathrm{v}]$ & das NICHT VOR dem essen essen \\
\hline [ [TR] & not e a $t$ before $t h$ e meal \\
\hline \multicolumn{2}{|r|}{ (2) } \\
\hline $\mathrm{PH}[\mathrm{v}]$ & hat gesagt er SPRITZT manchmal AUCH wenn der ZUCKer einfach zu HOCH \\
\hline PH [TR] & he sometimes also injects when the sugar is just too high \\
\hline [228] &..$(17) \quad 416[18: 48.3417[18: 48.6]$ \\
\hline $\begin{array}{l}\text { PH [v] } \\
\text { PH [TR] } \\
\text { [ [v] } \\
\text { [ [TR] }\end{array}$ & $\begin{array}{c}\text { ist we il e r zu HOCH is t } \\
\text { because it is too high } \\
\qquad \begin{array}{c}\text { ja } \\
\text { yes }\end{array}\end{array}$ \\
\hline [229] & $\begin{array}{lll} & 418[18: 54.8] & 419[18: 55.3](18)\end{array}$ \\
\hline $\begin{array}{l}\text { PH [v] } \\
\text { PH [TR] } \\
\text { [ [v] } \\
\text { [ [TR] }\end{array}$ & $\begin{array}{ll}\text { WICHtig dass man eine KLEIne DOsis nimmt.w e il es is t j a } & \\
\text { important that you take a small dose because it well it is } & \text { WEIL hab ich } \\
& \text { because before I did }\end{array}$ \\
\hline [230] &..$\quad 420[18: 5 A 21[19: 02.7]$ \\
\hline$[\mathrm{l}]$ & VORher die FRAge nicht verSTANden. hmhm \\
\hline [TR] & not understand the question \\
\hline \multicolumn{2}{|r|}{ ( } \\
\hline [233] & $425[19: 11.3](19)$ \\
\hline $\begin{array}{l}\text { PH [v] } \\
\text { PH [TR] } \\
\text { PAT [v] }\end{array}$ & $\begin{array}{l}\text { dann ist es } \\
\text { then it is } \\
\mathrm{hmhm}\end{array}$ \\
\hline [234] & $(20)$ \\
\hline $\begin{array}{l}\mathrm{PH}[\mathrm{v}] \\
\mathrm{PH}[\mathrm{TR}]\end{array}$ & $\begin{array}{l}\text { WICHtig dass er NICHT zuviel spritzt weil es ist nicht die GLEIche situaTION } \\
\text { important that he does not inject too much because it is not the same situation }\end{array}$ \\
\hline \multicolumn{2}{|r|}{1} \\
\hline [236] & $427[19: 24.4]$ \\
\hline$[\mathrm{l}]$ & üstü fazla iğne vurmamanızdır. \\
\hline [ [TR]x & it is most important that you do not inject too much in the afternoon \\
\hline $\begin{array}{l}\text { PAT [v] } \\
\text { PAT [TR] }\end{array}$ & $\begin{aligned} & \mathrm{h} \mathrm{m} \mathrm{hm} \mathrm{z} \mathrm{a} \mathrm{te} \mathrm{n} 0 \text { y ü } \mathrm{z} d \mathrm{e} \mathrm{nde} \\
& h m h m \text { that is exactly why I take little }\end{aligned}$ \\
\hline [237] & $428[19: 30.0]$ \\
\hline $\begin{array}{l}\text { I [ } \\
\text { I [TR] }\end{array}$ & well that is why he injects less \\
\hline PAT [v] & uyurke akşam o Novorapidden az vuruyorum. \\
\hline PAT [TR] & Novorapid in the evening before I go to sleep \\
\hline [238] & $429[19: 31.5] \quad 430[19: 33.5]$ \\
\hline $\mid \begin{array}{l}\mathrm{PH}[\mathrm{v}] \\
\mathrm{PH}[\mathrm{TR}]\end{array}$ & $\begin{array}{l}\text { das ist geNAU RICHtig } \\
\text { that is exactly right }\end{array}$ \\
\hline $\begin{array}{l}\text { [v] } \\
\text { I [TR] } \\
\text { PAT [v] } \\
\text { PAT [TR] }\end{array}$ & $\begin{array}{ll}\text { a m ABEND NovoRAPid WEniger SPRITzen } & \text { doğrudur bu diyo } \\
\text { Novorapid in the evening anyway } & \text { that is right she says } \\
& \begin{array}{l}\text { doktora bana anlattı. } \\
\text { the doctor told me }\end{array}\end{array}$ \\
\hline
\end{tabular}

Trying to explain the facts to the interpreter, she excludes the patient from the conversation and uses the third person for him. Nevertheless, the interpreter turns to the patient and translates the physician's explanation to the patient. The interpreter omits the deictic marker "then" (19) and the causal connector ("because") (20), reducing the transparency for the patient. Another distortion occurs when the interpreter states that the supply of insulin depends on the time of the day, when in fact the quantity depends on whether the insulin is injected immediately preceding a meal or not. The patient interrupts this discussion between the physician and interpreter by stating that he takes only a little Novorapid before going to sleep in the evening, signaling to the interpreter that he understands the physicians's instruction. After the patient's intervention, the physician confirms that his behaviour is "just right" (21). This again suggests that he understands the medical concepts better than the interpreter does. 


\section{Excerpt 5}

Although the physician confirms the correctness of the patient's routine at the end of excerpt 4 , she repeats the main message in excerpt 5 . Here, it can be assumed that the crucial message is more or less successfully passed on by the interpreter, even if the fact that the low dosage should be administered between meals is not explicitly mentioned by either her or the physician.

Table 5. Transcript of Excerpt 5

\begin{tabular}{|c|c|}
\hline [252] & $458[20: 33.8]$ \\
\hline $\begin{array}{l}\text { PH [v] } \\
\text { PH [TR] } \\
\text { PH [nv] }\end{array}$ & $\begin{array}{l}\text { a Iso WiCHtig ist EINfach dass Sie verSTEhen } \\
\text { well it is just important that you understand } \\
\text { [pointing to the data] }\end{array}$ \\
\hline [253] & 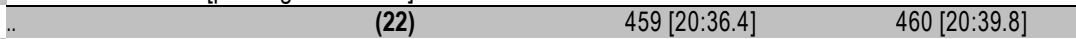 \\
\hline $\begin{array}{l}\text { PH }[v] \\
\text { PH [TR] } \\
\text { PAT }[v] \\
\text { PAT [TR] }\end{array}$ & $\begin{array}{l}\text { dass DIEse HOhen DOsen MIT ESsen und das OHne essen. } \\
\text { that these high doses with meals and that one without eating } \\
\qquad \begin{array}{l}\text { ja ja ja } \\
\text { yes yes yes }\end{array}\end{array}$ \\
\hline [254] & $461[20: 43.5] \quad 462[20: 44.4](23) \quad 463[20: 45.9] \quad 464[20: 46.2]$ \\
\hline $\begin{array}{l}\text { I }[v] \\
\text { I [nv] } \\
\text { I [TR] }\end{array}$ & $\begin{array}{l}\text { önemli olan bu yüksek dosisler yemekle birlikte bunuda yemekden yemeden. } \\
\text { [pointing to the data] } \\
\text { wh a } t \text { is i m p rt a } n t \text { is the high dose with the meal and that that one } \\
\text { with o ut e a ting to e at }\end{array}$ \\
\hline PAT [v] & $\mathrm{h} m \mathrm{~m} m \mathrm{~h} \mathrm{~m} h \mathrm{~m}$ \\
\hline
\end{tabular}

The interpreter points to the data as the physician has done. As we have seen in excerpts 2 to 4 , the interpreter has not acquired appropriate knowledge prior to the consultation, which would have enabled the interpreter to transfer the medical concept correctly (cf. Albl-Mikasa, 2007, p. 130f; Crezee, 2013). To compensate for the lack of medical knowledge, it would have been essential for the interpreter to have paid attention to the microstructural patterns of the conjunctions ("if - then", "because") or to the adverbial phrases ("with meals and that one without eating" [22]) which the physician repeats several times. The almost verbatim transfer of the physician's words of just this small part of excerpt 5 (23) might indicate that the interpreter recalls the wording without understanding the concept behind the words (see Schnotz 2006, p. 775). As the physician does not understand Turkish, she does not seem to notice that the interpreter's more or less verbatim version conveys the message in excerpt 5 more adequately than before. Had the interpreter really understood the concept at this point, she could have added "the small dose" as we have already seen her do in excerpt 1 (by adding "aim") "because a full reconstruction might help the meaning not to be lost" (Tebble, 2009, p. 215). Indeed, the syntactic pattern alone should have alerted the interpreter to such a solution even if she did not understand the concept (cf. Schnotz, 2006, p. 775).

\section{Excerpt 6}

The physician repeats, about a minute later in excerpt 6 , that the "high dose is meant for with meals and this small one without meals" (24). The message should be clear enough, provided the interpreter and the patient can see where the physician is pointing.

In excerpt 6 the interpreter's delivery proves to be inadequate again: "That is with the meal and that is, if you well take a reading before the meal and inject insulin." (25) While we should give the interpreter credit for referring correctly to the appropriate data by using the deictic pronoun ("that is with the meal ... and that is ... before the meal") - the interpreter this time leans forward to be able to look at the data and even points to it - the crucial problem of misusing the preposition "before" (instead of "between") meals remains, which again distorts the message that the physician wants to transmit. 
Table 6. Transcript of Excerpt 6

\begin{tabular}{|c|c|c|}
\hline [267] & 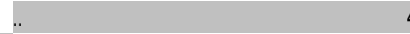 & $481[21: 43.2]$ \\
\hline $\mathrm{PH}[\mathrm{v}]$ & & also was MIR einfach WICHtig ist dass er \\
\hline PH [TR] & & so it is just important for me that he understands \\
\hline [268] & \multicolumn{2}{|c|}{$483[21: 47.7]$} \\
\hline $\begin{array}{l}\text { PH [V] } \\
\text { PH [TR] }\end{array}$ & \multicolumn{2}{|c|}{$\begin{array}{l}\text { v e r S T E H Tdass DIEse HOhe DOsis (.) geDACHT ist für mit dem ESsen (.) } \\
\text { that this high dosis (.) is intended to be with meals }\end{array}$} \\
\hline [269] & $484[21: 52.7(24)$ & $485[21: 56.4]$ \\
\hline $\begin{array}{l}\text { PH [v] } \\
\text { PH [TR] }\end{array}$ & \multicolumn{2}{|c|}{$\begin{array}{l}\text { und diese KLEIne (.) OHNE ESsen } \\
\text { and this small one without meals }\end{array}$} \\
\hline$\left[\begin{array}{l}1 \\
{[}\end{array}\right]$ & & $\begin{array}{l}\text { benim için önemli olan anlaması için diyo bu } \\
\text { [pointing to the data] }\end{array}$ \\
\hline [ [TR] & & for me it is important that he understands she says \\
\hline [270] & & $(25)$ \\
\hline I $[\mathrm{v}]$ & \multirow{2}{*}{\multicolumn{2}{|c|}{$\begin{array}{l}\text { yemekle birlikte bunu da yemek yemeden önce ölçüyorsunuz yani } \\
\text { that is with the meal and that is if you well take a reading before the meal and inject insulin }\end{array}$}} \\
\hline [ [TR] & & \\
\hline [271] & .. $486[22: 01.2]$ & $487[22: 04.4]$ \\
\hline [ [ $[\mathrm{v}]$ & \multicolumn{2}{|l|}{ vuruyorsunuz. } \\
\hline
\end{tabular}

\section{Excerpt 7}

Only a quarter of a minute later, in excerpt 7 , the timing issue still appears to be on the interpreter's mind:

Table 7. Transcript of Excerpt 7

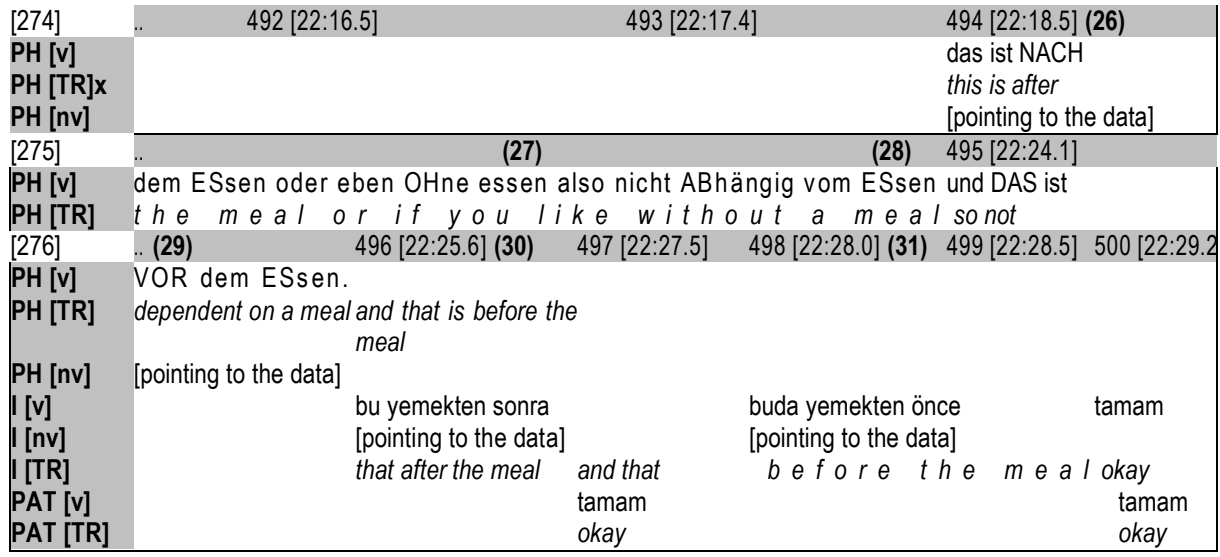

The physician wants to be explicit by restating the important facts twice: The first paraphrase for "after the meal" (26) is "if you like without a meal" (27) and the second paraphrase is "(so) not dependent on meals" (28). She then adds "before the meal" (29). The interpreter simply conveys "after the meal" (30) and "before the meal" (31), which is not what the physician meant. The problem is not the omission of the physician's additional explanations, "if you like without meals" (27) and "not dependent on meals" (28) as such, but that the interpreter has simply clung to the lexical items "before" (31) or "after" the meal (30), without clarifying that the insulin dosage should be adjusted according to food intake. That the physician repeated the information twice may have made the task more difficult for the interpreter. She has to listen to the elliptic substitutions and look at the data in the record referred to by the physician (in the video the interpreter is seen to lean forward and to point to the data). She then has to disambiguate the pronoun "that"; recognise the adverbial "if you like" (27) and the connector "so ..." (28), which both signal paraphrasing; and, finally, she has to reformulate the physician's utterance. These are demanding "non-automatic" tasks which "take up processing capacity" (cf. Gile 2009, p. 224). Nevertheless, the interpreter still does not seem to understand the concept of how to maintain optimal blood glucose levels on which the consultation has centred since excerpt 2. 


\section{Excerpt 8}

Towards the end of the ten minutes, the physician emphatically repeats her crucial message once more:

Table 8. Transcript of Excerpt 8

\begin{tabular}{|c|c|}
\hline [306] & 559 [24:55.4] \\
\hline $\begin{array}{l}\mathrm{PH}[\mathrm{v}] \\
\mathrm{PH}[\mathrm{TR}]\end{array}$ & $\begin{array}{l}\text { und WICHtig ist für mich EINfach dass Sie wenn Sie der ZUcker HOCH ist } \\
\text { and it is important for me that if the sugar is high that you do not inject too }\end{array}$ \\
\hline [307] & $560[25: 06.7]$ \\
\hline $\begin{array}{l}\mathrm{PH}[v] \\
\mathrm{PH}[\mathrm{TR}]\end{array}$ & $\begin{array}{l}\text { dass Sie NICHT zuVIEL insuLIN SPRITzen OHne zu Essen, dass er NICHT zu } \\
\text { much insulin without eating, that you don't end up with hypoglycaemia. }\end{array}$ \\
\hline [308] & $\begin{array}{lll}. . & 561[25: 08.7] & 562[25: 10.6] \\
\end{array}$ \\
\hline $\begin{array}{l}\mathrm{PH}[\mathrm{v}] \\
\text { [ [v] } \\
\text { [TR] }\end{array}$ & $\begin{array}{l}\text { UNterzuckerung KOMMT. } \\
\qquad \begin{array}{l}\text { benim için önemli olan diyo } \\
\qquad \text { hat is important for me she say s }\end{array}\end{array}$ \\
\hline [309] & $\begin{array}{ll}(32) & 563[25: 15.4]\end{array}$ \\
\hline $\begin{array}{l}\text { PH [v] } \\
\text { PH [TR] } \\
\text { [ [v] } \\
\text { [ [TR] }\end{array}$ & $\begin{array}{ll}\text { zucker zu HOCH ist nicht zuVIEL SPRITzen haben Sie gesagt. } & \text { aLso er hat ich } \\
\text { er if the sugar is too high don't inject too much you said. }\end{array}$ \\
\hline $\begin{array}{l}{[310]} \\
\text { PH [v] } \\
\text { PH [TR] }\end{array}$ & $\begin{array}{l}\text { weiss nicht ich habe das geFÜHL wir verSTEhen uns nicht GANZ. em er hat } \\
\text { I don't know I feel we don't really understand each other. um he said }\end{array}$ \\
\hline [311] & \\
\hline $\begin{array}{l}\mathrm{PH}[\mathrm{v}] \\
\mathrm{PH}[\mathrm{TR}]\end{array}$ & $\begin{array}{l}\text { geSAGT er SPRITZT manchmal AUCH wenn der zucker HOCH ist insuLIN } \\
\text { he sometimes also injects insulin if the sugar is high because }\end{array}$ \\
\hline [312] & . (33) $\quad 565[25: 28.1]$ \\
\hline $\begin{array}{l}\mathrm{PH}[v] \\
\mathrm{PH}[\mathrm{TR}]\end{array}$ & $\begin{array}{l}\text { weil der zucker zu HOCH ist OHne zu ESsen das haben Sie AUCH SO } \\
\text { the sugar is too high without eating that is how you understood it, too, didn't you? }\end{array}$ \\
\hline [313] & $566[2567[25: 30.4]$ \\
\hline $\begin{array}{l}\text { PH [v] } \\
\text { PH [TR] } \\
\text { [ [v] } \\
\text { [ [TR] }\end{array}$ & $\begin{array}{l}\text { ver S T A N d e n ODER? h m h m und ich möchte dass er in DIEsen situaTIOnen } \\
\qquad \begin{array}{l}\text { j a ge N A U j a } \\
\text { yes preciselym and I would like him to inject only the small }\end{array}\end{array}$ \\
\hline $\begin{array}{l}{[314]} \\
\text { PH [v] } \\
\text { PH [TR] }\end{array}$ & $\begin{array}{l}\text { NUR die KLEIne DOsis insuLIN SPRITZT und NICHT EINfach IRgend } \\
\text { dose of insulin in these situations und not just anything }\end{array}$ \\
\hline [315] & $568[25: 40.5]$ \\
\hline $\begin{array}{l}\text { PH [v] } \\
\text { PH [TR] } \\
\text { [ [v] } \\
\text { [ [TR] }\end{array}$ & $\begin{array}{l}\text { ETwas oder da OBEN weil DAS macht unterZUckerung } \\
\text { or up here because this leads to a hypo } \\
\qquad \begin{array}{l}\text { wenns } \mathrm{HOCH} \text { ist das } \\
\text { if it is high is that }\end{array}\end{array}$ \\
\hline [316] & $569[25: 42.3](36) \quad 570[25: 44.8]$ \\
\hline $\begin{array}{l}\text { PH [v] } \\
\text { PH [TR] } \\
\text { I [V] } \\
\text { [ [TR] } \\
\text { [ [V] }\end{array}$ & 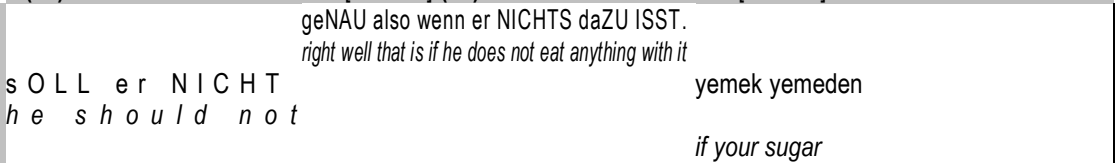 \\
\hline [317] & $571[25: 47.7](37)$ \\
\hline $\begin{array}{l}\text { PH [v] } \\
x \\
\text { PH [nv] } \\
\text { [ [v] } \\
\text { [ [TR] }\end{array}$ & 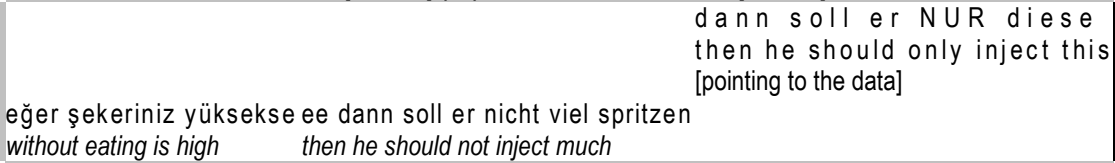 \\
\hline [318] & $573[25: 53.6]$ \\
\hline $\begin{array}{l}\mathrm{PH}[v] \\
\mathrm{PH}[\mathrm{TR}]\end{array}$ & $\begin{array}{l}\text { DOsis hier UNten SPRITzen wenn er EINfach den ZUcker korriGIEren will weil } \\
\text { dose down here if he just wants to adjust the sugar because it is too high }\end{array}$ \\
\hline [319] & .. $574[25: 57.2] \quad(38)$ \\
\hline $\begin{array}{l}\text { PH }[v] \\
\text { [V] } \\
\text { [TR] }\end{array}$ & $\begin{aligned} \text { er zu HOCH is t } & \\
& \text { şeker eğer yüksekse kore korigiere yapmak istiyosanız kontrol } \\
& \text { if the sugar is high you want to adjust check it she says }\end{aligned}$ \\
\hline [320] & $575[26: 02.7]$ \\
\hline $\begin{array}{l}\text { [v] } \\
\text { [nv] } \\
\text { ITR] }\end{array}$ & $\begin{array}{l}\text { etmek istiyorsanız diyoki fazla iğne vurmayın dosisini yükseltmeyin burdaki } \\
\qquad \begin{array}{l}\text { [pointing to the data] } \\
\text { do not inject to much she says do not increase the dose }\end{array}\end{array}$ \\
\hline
\end{tabular}

On three occasions, the interpreter intervenes with a question. The first time she tries to ascertain whether it is correct to tell the patient not to "inject too much" (32) if the sugar level is too high. The physician realizes that the interpreter has not fully understood the message and tries to find out if they are both talking about the patient's high blood sugar when he is not eating (33), and 
then repeats that the patient should inject only "the small dose" (34). The interpreter starts again, but does not finish her interpretation of the instruction: "If it is high is that, he should not" (35). The physician then adds the second part of the medication rule: "right well that is if he does not eat anything with it" (36). The physician again talks to the interpreter, using the third person for the patient, as in excerpt 6 . Finally, for the first time after ten minutes and after again checking with the physician (37), the interpreter actually manages to convey the conditional relation between the propositions: "if the blood sugar level is high you want to adjust, check it, she says - do not inject too much" (38). However, as she omits the adverbial "without eating", the statement remains incomplete, in spite of the physician's help in suggesting a more precise wording.

\section{Excerpt 9}

The physician concludes by asking the interpreter: "Has he understood?"

Table 9. Transcript of Excerpt 9

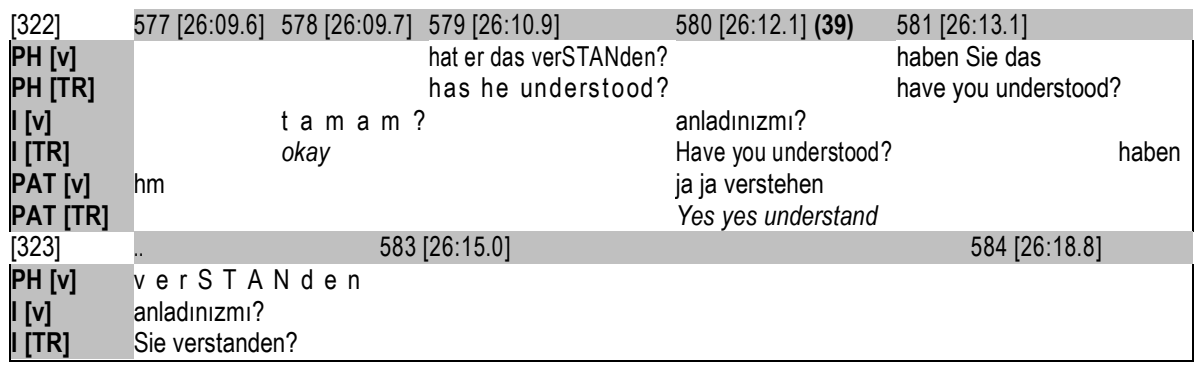

The patient answers (again) in German "Ja, ja, verstehen" (39) ("Yes, yes, understand"). Only after the patient responds does the physician ask him directly if he understands her explanations. The patient understands more or less, while the interpreter fails to interpret adequately the information given by the physician.

\section{Discussion and Conclusion}

Excerpts 1 - 9 above are part of a diabetes consultation where an interpreter had been called on to facilitate the communication between a physician and a patient who did not share the same language. It took the interpreter ten minutes to reformulate the following instructions more or less adequately with the help of the physician:

(1) If the patient takes insulin while eating, then insulin must be supplied in a high quantity because the blood sugar level rises considerably during meals and can only be lowered to a normal level with a high dose of insulin.

(2) If the patient takes insulin between meals, then insulin must be injected in a much lower quantity because otherwise the blood sugar level gets too low, inducing hypoglycaemia.

In the situation, the interpreter distorts both the effect of the medication ("so that it goes up" instead of "because it goes up") and, above all, crucial information on when and in what doses the medication should be taken ("before or after meals" instead of "between meals") (cf. Nicodemus et al., 2014). On the basis of the data available, it is not possible to say whether it was the physician's repetitious use of the conjunctions and lexical items or her "prompting" in the latter stages of the exchange that finally allowed the interpreter to render the intended propositions more or less accurately (see 
excerpt 7). As far as the interpreter is concerned, a major issue seems to be domain-specific knowledge. To be able to communicate the link between food intake and insulin supply efficiently and effectively to the patient, she would have needed a degree of domain expertise she clearly lacks. Failing this knowledge, interpreters should possess compensation mechanisms to identify bottom-up linguistic indicators to help them bridge the knowledge gaps. In this particular consultation, such indicators lie in the repetitious syntactic patterns of the two general cause-and-effect relations and the explanations presented by the physician (see 1 and 2 above), as well as in cohesive ties such as lexical repetitions. Recognizing these would have greatly helped the interpreter to communicate the instructions adequately (cf. Hofer et al., 2013b).

The problems seen and discussed in this paper are not caused by the interpreter alone (cf. Hale \& Ozolins, 2009). Indeed, the physician could and should have facilitated communication with the patient who signals (partly in German) that he would like to be actively engaged in the conversation. She could have shown more "response appropriateness" (Koenig et al., 2014, p. 5) towards the patient instead of ignoring his utterances several times (cf. Rivadeneyra et al., 2000). She could then perhaps have realized that he might in fact have understood her instructions better than the interpreter instead of thinking it was the patient who did not understand the information. One further point is that the physician could have displayed greater contextual sensitivity by speaking more explicitly, finishing her sentences and clarifying deictic markers and pronominal substitutions so that the interpreter could have understood the blood glucose-insulin mechanism more easily.

As a consequence of the shortcomings shown by both the interpreter and the physician, the Turkish diabetes patient receives less precise information from the physician than the interpreter does. It is therefore likely that the effort he needs to make in order to understand the instructions is greater than if he had been able to use his mother tongue with the physician (cf. Menz, 2013, p. 348). Moreover, he is not included in the interactions when the interpreter asks the physician for clarifications (excerpts 4 and 8). Especially in excerpts 4 and 8 the interpreter speaks to the physician without interpreting her questions for the patient with the result that the patient must feel excluded from the interaction. Similar discourse behaviours have been observed by other researchers (e.g. Menz et al., 2013; Meyer et al., 2003). In this situation, the patient is poorly informed by the interpreter, and this part of the consultation is unnecessarily lengthened because the physician has to explain the role of insulin several times. She may be thinking it is the patient who does not understand rather than the interpreter.

The results presented in this paper hold practical implications for continuing professional development programmes. Systematic exposure to models of discourse analysis and discourse comprehension as well as cognitive processing can provide invaluable support in helping interpreters to reproduce discourses adequately by means of "formal, logical reasoning, as well as other types of inference and problem-solving activities" (Van Dijk \& Kintsch, 1983, p. 341f). However, a key issue in training medical interpreters in Switzerland is certainly domain-specific knowledge as argued by Crezee (2013). This is all the more important as the consultation in this case study concerns diabetes, a rather common disorder.

\section{Acknowledgement}

We are extremely grateful to Kenan Hochuli for the revision of the translation of the Turkish passages into German and to Gary Massey for revising the translation of this paper into English. I would also like to thank the reviewers and the editors for their help and their valuable suggestions. 


\section{References}

Albl-Mikasa, M. (2012). Notationssprache und Notizentext: Ein kognitiv-linguistisches Modell für das KonsekutivdoImetschen. Tübingen: Narr.

Crezee, I. (2013). Introduction to healthcare for interpreters and translators. Amsterdam/ Philadelphia: John Benjamins.

Gile, D. (2009). Basic concepts and models for interpreter and translator training. (revised ed.).Amsterdam/ Philadelphia: John Benjamins.

Hudelson, P., Dao, M. D., Perron, N. J., \& Bischoff, A. (2013). Interpreter-mediated diabetes consultation: a qualitative analysis of physician communication practices. BMC Family Practice, 14. doi: 10.1186/1471-2296-14-163.

Hale, S., \& Ozolins, U. (2007). Introduction. Quality in Interpreting - a shared responsibility. In S. Hale, U. Ozolins \& L. Stern (Eds.), Critical Link 5. Quality in Interpreting: A shared responsibility, 1-12. Sydney, John Benjamins.

Hofer, G., Eggler, M., Langewitz, W., \& Sleptsova, M. (2013a). Ich habe das Recht zu schweigen. In A.K. Ende, S. Herold \& A. Weilandt (Eds.), Alles hängt mit allem zusammen. Festschrift für Peter A. Schmitt (pp. 313-329). Berlin, Frank \& Timme.

Hofer, G., Eggler, M., Langewitz, W., \& Sleptsova, M. (2013b). Sind es Schmerzen, die neu sind oder die sie schon von vorher kennen? In M. Carroll, S. Herwig \& A. Remael (Eds.), Mapping the field of community interpreting (pp. 313-329). Berlin, ICWE.

Menz F. (2013). Zum Vergleich von ärztlichen Konsultationen zu Kopfschmerzen bei gedolmetschten und nicht gedolmetschten Gesprächen. In F. Menz (Ed.), Migration und medizinische Kommunikation: Linguistische Verfahren der Patientenbeteiligung und Verständnissicherung in ärztlichen Gesprächen mit MigrantInnen (pp. 309-352). Wien: v \& r, Vienna University Press.

Meyer, B. (2009). Deutschkenntnisse von Migrant/innen und ihre Konsequenzen für das Dolmetschen im Krankenhaus. In D. Andres \& S. Pöllabauer (Eds.), "Spürst du, wie der Bauch rauf-runter?" Fachdolmetschen im Gesundheitsbereich (pp. 139-157). München: Meidenbauer.

Meyer, B., Apfelbaum, B., Pöchhacker, F., \& Bischoff, A. (2003). Analysing Interpreted Doctor-Patient Communication from the Perspectives of Linguistics, Interpreting Studies and Health Sciences. In L. Brunette, G. Bastin, I. Hemlin \& H. Clarke (Eds.), The Critical Link 3: Interpreters in the Community, 67-79. Selected papers from the Third International Conference on Interpreting in Legal, Health and Social Service Settings, Montréal, Quebec, Canada 22-26 May 2001. Amsterdam and Philadelhia: John Benjamins.

Nicodemus, B., Swabey, L., \& Moreland, C. (2014). Conveying medication prescriptions in American sign language: Use of emphasis in translations by interpreters and deaf physicians. Translation and Interpreting, 6(1), 1-22.

Rivadeneyra, R., Elderkin-Thompson, V., Silver, R.C., \& Waitzkin, H. (2000). Patient centeredness in medical encounters requiring an interpreter. Am J Med, 108(6), 470-474.

Selting, M., Auer, P., \& Barth-Weingarten, D. (2009). Gesprächsanalytisches Transkriptionssystem GAT (GAT 2). Gesprächsforschung - Online Zeitschrift zur verbalen Interaktion, 10, 353-402.

Tebble, H. (2007). What can interpreters learn from discourse studies? In S. Hale, U. Ozolins \& L. Stern (Eds.), The Critical Link 5. Quality in Interpreting - a shared responsibility, 201-219. Sydney, Australia: John Benjamins.

Schnotz, W. (2006). Textverständnis. In D. H. Rost (Ed.), Handwörterbuch pädagogische Psychologie (pp. 769 -778). Weinheim: Beltz.

Sleptsova, M., Hofer, G., Morina, N., \& Langewitz, W. (2014) The role of the health care interpreter in a clinical setting-a narrative review. Community Health Nursing, 31(3), 167-84. doi: 10.1080/07370016.2014.926682.

Van Dijk, T. A., \& Kintsch, W. (1983). Strategies of Discourse Comprehension. New York: Academic Press. 
Appendix A

The transcription conventions used in the excerpts presented are the following:

Capital letters $=$ stressed syllables in the German text

$()=$. pause for less than 0:2 seconds

$(-)=$ pause between $0: 2$ and 0:5 seconds

$[\mathrm{v}]=$ verbal utterance

$[\mathrm{nv}]=$ non-verbal communication

The translation of the German and Turkish utterances into English appear in italics. To shorten the transcript, some parts within a transcript are omitted. The passages in question are indicated by ellipsis marks (....). The German and the Turkish utterances were translated into English by the authors of the article. 